\title{
JNTTIP
}

DOI : 10.24198/jnttip.v2i2.27692

Jurnal Nutrisi Ternak Tropis dan IImu Pakan

jurnal.unpad.ac.id/jnttip; e-ISSN:2715-7636

2(2):71-77, Juni 2020

\section{KANDUNGAN ASAM LAKTAT DAN PH SILASE PELEPAH PISANG DENGAN PENAMBAHAN LUMPUR KECAP SEBAGAI ADITIF}

\section{The Content of Lactic Acid and pH of Banana Stem Silage With Addition of Soy Sauce Sludge as Additive}

\author{
Mohamad Haris Septian"1, T. Dhalika², dan A. Budiman² \\ ${ }^{1}$ Dosen, Prodi Peternakan Fakultas Pertanian Universitas Tidar, Magelang \\ ${ }^{2}$ Dosen, Fakultas Peternakan Universitas Padjadjaran, Sumedang
}

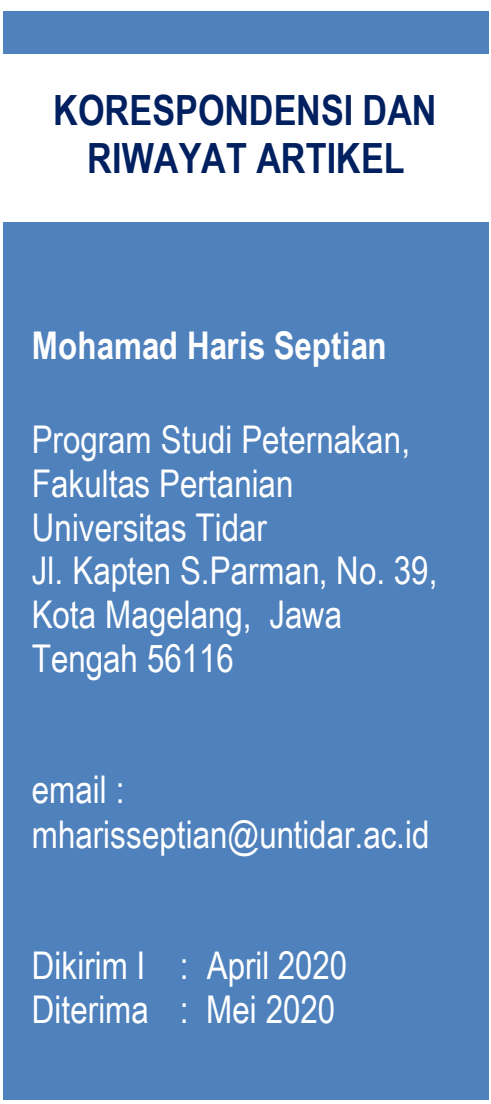

\begin{abstract}
ABSTRAK
Tujuan Penelitian ini untuk mengetahui pengaruh penambahan lumpur kecap terhadap kandungan asam laktat dan $\mathrm{pH}$ silase pelepah pisang, Penelitian ini menggunakan metode eksperimental dengan Rancangan Acak Lengkap. Terdapat empat perlakuan, yaitu tingkat penambahan lumpur kecap: $\mathrm{P} 1=$ penambahan lumpur kecap 1\%, P2 = penambahan lumpur kecap 3\%, P3 = penambahan lumpur kecap 5\%, dan $\mathrm{P} 4=$ penambahan lumpur kecap 7\%, masing-masing perlakuan diulang sebanyak lima kali. Data yang terkumpul dianalisis secara statistik dengan menggunakan analisis ragam dan dilanjutkan dengan uji Jarak Berganda Duncan. Peubah yang diamati adalah konsentrasi asam laktat dan $\mathrm{pH}$ silase pelepah pisang. Hasil penelitian menunjukkan bahwa penambahan lumpur memberikan pengaruh nyata $(\mathrm{P}<0,05)$ terhadap kandungan asam laktat dan $\mathrm{pH}$ silase pelepah pisang. Penambahan aditif lumpur kecap sebanyak 5\% dapat menghasilkan kandungan asam laktat silase pelepah pisang tertinggi dan penggunaan aditif lumpur kecap sebanyak 3\% menghasilkan kandungan $\mathrm{pH}$ silase pelepah pisang terendah.
\end{abstract}

Kata Kunci: lumpur kecap, pelepah pisang, silase.

\section{ABSTRACT}

The aim this study was to find out the effect of soy souce sludge addtion to content of lactic acid and $\mathrm{pH}$ silage of banana stem.The study was conducted experimentally with Completely Randomized Design. There are four treatments: $P 1=$ silage with soy sauce sludge $1 \%, P 2=$ silage with soy sauce sludge $3 \%, P 3=$ silage with soy sauce sludge $5 \%$, and P4 = silage with soy sauce sludge 7\%, each of which was replicatedted five times. The data were analyzed with statistically by using analysis of variance then continued with the Duncan's Multiple Range Test. The variables observed were the concentration of lactic acid and the $\mathrm{pH}$ of the banana 
stem silage. The results showed that the addition of soy sauce sludge had a significant effect ( $P$ $<0.05)$ on the content of lactic acid and the $\mathrm{pH}$ of the banana stem silage. The addition of soy sauce sludge as much as $5 \%$ produced the highest lactic acid content of banana stem silage and the use of soy sauce sludge as much as $3 \%$ produced the lowest $\mathrm{pH}$ content of banana stem silage.

Keyword: soy sauce sludge, banana stem, silage

\section{PENDAHULUAN}

Pemenuhan kebutuhan pakan ruminansia akan sulit jika harus bergantung pada produksi rumput. Pemanfaatan produk samping atau limbah pertanian, perkebunan, dan industri pangan sebagai bahan pakan merupakan tindakan bijaksana dalam pemenuhan kebutuhan pakan. Pelepah pisang merupakan limbah dari perkebunan pisang yang tidak dapat dimanfaatkan lagi sebagai bahan pangan, namun telah banyak dimanfaatkan sebagai pakan ternak. Pisang banyak tersedia di Indonesia dan merupakan buah yang produksinya paling tinggi di Indonesia. Luas Panen perkebunan pisang di Indonesia tahun 2019 adalah $105.801 \mathrm{Ha}$ dengan produksinya sebanyak 7.280.658 ton (Badan Pusat Statistik, 2019). Ffoulkes et al. (1977) menyatakan bahwa perbandingan buah pisang, daun dan batang (pelepah) berturut-turut adalah 26\%, 15\%, dan 59\% sedangkan berdasarkan bahan keringnya adalah 37\%, 25\% dan 39\%. Jika dihitung berdasarkan perbandingan tersebut maka produksi pelepah pisang di Indonesia mencapai 16.521.493 ton segar atau 1.097.027 ton berdasarkan bahan kering dalam tahun yang sama. Melihat dari luas panen dan produksinya serta tersedia di semua wilayah Indonesia maka pelepah pisang sangat berpotensi untuk dijadikan sebagai pakan non konvensional untuk mensubtitusi kebutuhan hijauan rumput bagi ruminansia.

Dibalik potensi produksinya yang melimpah pelepah pisang memiliki batasan dalam penggunannya dikarenakan kandungan airnya yang sangat tinggi yaitu 93,34\%, hal ini dapat mengakibatkan pelepah pisang cepat busuk jika disimpan dalam waktu yang lama. Kandungan protein kasar yang rendah menambah kendala dari kendala-kendala lainnya. Komposisi zat makanan berdasarkan bahan kering, batang (pelepah) pisang mengandung protein kasar $3,26 \%$, serat kasar $21,61 \%$, lemak kasar $0,35 \%$, abu $15,75 \%$, dan bahan ekstrak tanpa nitrogen 59,03\% (Laboratorium Nutrisi Ternak Ruminansia dan Kimia Makanan Ternak, 2011).

Teknologi pengolahan pakan dengan fermentasi anaerob atau silase dinilai dapat meminimalisir batasan dari penggunaan pelepah pisang. Cara ini sudah lama digunakan untuk pengawetan pakan, terutama untuk bahan pakan Pengolahan pelepah pisang dengan cara fermentasi anaerob diyakini dapat mengawetkan dan meningkatkan kecernaan pelepah pisang. Perlu adanya penambahan bahan aditif untuk menambah kualitas silase pelepah pisang, dikarenakan kandungan karbohidrat mudah larut dari pelepah pisang yang masih rendah. Karbohidrat mudah larut akan dimanfaatkan oleh mikroba untuk tumbuh kembangnya.

Bahan aditif yang dapat digunakan salah satunya adalah lumpur kecap. Lumpur kecap memiliki kandungan karbohidrat mudah larut yang cukup tinggi yaitu 77,54\%. Lumpur kecap merupakan bahan aditif yang dapat merangsang pertumbuhan bakteri asam laktat, serta menghasilkan asam laktat yang lebih banyak dibandingkan dengan penggunaan molasses (Lukmansyah, dkk., 2009). Senjaya dkk. (2010) menyatakan bahwa karbohidrat larut yang tinggi sangat menentukan produksi asam terutama asam laktat dan asam organik lainnya di dalam proses ensilase sehingga dapat mempercepat penurunan derajat keasaman. Menurut Bolsen (1993), suasana asam akan menghambat kinerja enzim protease yang menyebabkan deaminasi protein, sehingga 
pembentukan amonia berkurang. Oleh karena itu asam laktat dapat dikatakan juga sebagai bahan pengawet yang terdapat dalam silase.

Penelitian ini bertujuan untuk mengetahui pengaruh penambahan lumpur kecap terhadap kandungan asam laktat dan $\mathrm{pH}$ ekstrak cairan fermentasi anaerob pelepah pisang, serta untuk mengetahui persentase penggunaan lumpur kecap yang dapat menghasilkan silase pelepah pisang dengan asam laktat tertinggi dan $\mathrm{pH}$ terendah.

\section{MATERI DAN METODE}

Materi yang digunakan dalam penelitian adalah pelepah pisang yang telah dipanen buahnya, lumpur kecap diperoleh dari PD. 2 Sekawan FAA, Desa Wantilan Kecamatan Cipeundeuy, Kabupaten Subang. Penelitian ini dilaksanakan dengan metode ekpeprimental rancangan acak lengkap. Terdiri dari 4 perlakuan dan 5 ulangan yaitu: $\mathrm{P} 1=$ pelepah pisang ditambah $1 \%$ lumpur kecap, P2=pelepah pisang ditambah 3\% lumpur kecap, $\mathrm{P} 3=$ pelepah pisang ditambah 5\% lumpur kecap, dan $\mathrm{P} 4=$ pelepah pisang ditambah 7\% lumpur kecap.

\section{Pembuatan Silase Pelepah Pisang}

Pelepah pisang dipotong dari tanamannya lalu dianginkan selama satu hari untuk menghilangkan sebagian kadar air dan getahnya. Pelepah pisang di cacah dengan ukuran 3-5 cm, cacahan tersebut ditimbang sebanyak $1 \mathrm{~kg}$ untuk masing-masing silo yang terbuat dari plastik lalu ditambahkan lumpur kecap sesuai perlakuan. Campuran tersebut dipadatkan dan dihampa udarakan untuk meminimalisir adanya oksigen di dalam silo. Bahan silase difermentasi selama 21 hari.

\section{Parameter Penelitian}

Parameter yang diamati dari penelitian adalah kandungan asam laktat dan $\mathrm{pH}$ silase pelepah pisang. Pengukuran kandungan asam laktat menggunakan metode Cappucino dan Sherman (1991). Pengukuran $\mathrm{pH}$ silase dilakukan dengan menggunakan $\mathrm{pH}$ meter yang telah dikalibrasi menggunakan larutan buffer $\mathrm{pH} 4$ dan $\mathrm{pH} 7$. Analisis asam laktat dan $\mathrm{pH}$ dilaksanakan di Laboratorium Nutrisi Ternak Ruminansia dan Kimia Makanan Ternak Fakultas Peternakan Universitas Padjadjaran.

\section{Analisis Statistika}

Data yang terkumpul dianalisis menggunakan IBM SPSS 23 dengan Rancangan Acak Lengkap dan analisis statistik menggunakan sidik ragam dan dilanjutkan dengan uji jarak berganda Duncan.

\section{HASIL DAN PEMBAHASAN}

Berdasarkan hasil penelitian, rataan kandungan asam laktat setiap perlakuan berkisar antara $0,25 \%$ sampai dengan $0,61 \%$. Hasil analisis ragam menunjukkan bahwa perlakuan penambahan lumpur kecap pada fermentasi anaerob memberikan pengaruh nyata $(\mathrm{P}<0,05)$ terhadap kandungan asam laktat ekstrak cairan fermentasi anaerob pelepah pisang Hasil analisis uji kandungan asam laktat disajikan pada Tabel 1 .

Kandungan asam laktat terendah diperoleh pada perlakuan $\mathrm{P} 1$ dengan rataan produksi asam laktat $0,25 \%$ dan tertinggi pada perlakuan $\mathrm{P} 3$ dengan rataan produksi asam laktat $0,61 \%$, namun pada tingkat penggunaan lumpur kecap lebih dari 5\% terjadi penurunan produksi asam laktat. Produksi asam laktat meningkat dengan meningkatnya penambahan lumpur kecap, tetapi akan mencapai kejenuhan pada tingkat penggunaan tertentu.

Adanya perbedaan kandungan asam laktat ini dapat dikarenakan adanya perbedaan kandungan karbohidrat mudah larut dari penambahan lumpur kecap di dalam bahan penelitian. Bakteri asam laktat memanfaatkan karbohidrat mudah larut yang terdapat dalam pelepah pisang dan lumpur kecap menjadi sumber energinya. Lumpur 
kecap merupakan aditif yang kaya akan kandungan karbohidrat terlarut yang tercermin dari nilai BETNnya yang tinggi. Lumpur kecap mengandung air sebesar $12,58 \%$ dan komposisi zat makanannya berdasarkan bahan kering mengandung abu bakteri Clostridisal yang dapat merubah asam laktat menjadi asam butirat (Bolsen, 1993), maka pada pemberian lumpur kecap lebih dari 5\% akan menyebabkan asam laktat menurun.

Berdasarkan analisis sidik ragam

Tabel 1. Pengaruh Penambahan Lumpur Kecap terhadap Kandungan Asam Laktat dan pH silase Pelepah Pisang

\begin{tabular}{lcccc}
\hline \multirow{2}{*}{ Parameter } & \multicolumn{4}{c}{ Perlakuan } \\
\cline { 2 - 5 } & P1 & P2 & P3 & P4 \\
\hline Asam Laktat & $0,25 \pm 0,01^{\mathrm{a}}$ & $0,34 \pm 0,01^{\mathrm{b}}$ & $0,61 \pm 0,04^{\mathrm{d}}$ & $0,48 \pm 0,02^{\mathrm{c}}$ \\
$\mathrm{pH}$ & $5,15 \pm 0,15^{\mathrm{b}}$ & $4.48 \pm 0,05^{\mathrm{a}}$ & $4.44 \pm 0,14^{\mathrm{a}}$ & $4.45 \pm 0,20^{\mathrm{a}}$ \\
\hline
\end{tabular}

Keterangan: Superskrip yang berbeda dalam baris yang sama menunjukkan perbedaan yang nyata $(\mathrm{P}<0,05)$

$4,15 \%$, protein kasar 2,6\%, serat kasar $0,98 \%$, lemak kasar 2,15\%, BETN 77,54\% (Laboratorium Nutrisi Ternak Ruminansia dan Kimia Makanan Ternak, 2008). Menurut Sutowo et.al (2016), bahwa karbohidrat merupakan sumber energi yang mudah dimanfaatkan oleh bakteri asam laktat untuk memproduksi asam laktat. Fermentasi silase yang baik didominasi oleh BAL dan menghasilkan konsentrasi asam organik yang didominasi oleh asam laktat (Pangestu dkk., 2003; Chen dan Weinberg, 2008; Tanuwiria, 2007a,b).

Berdasarkan penelitian ini pemanfaatan zat makanan dalam lumpur kecap oleh mikroba selama fermentasi mengalami titik jenuh, hal ini terlihat pada perlakuan P4 yang mengalami penurunan kandungan asam laktat. Penurunan kandungan asam laktat diduga karena terlalu tingginya kandungan karbohidrat yang menyebabkan mikroba tidak dapat lagi memanfaatkan zat makanan didalamnya, karena asam laktat yang dihasilkan telah menghentikan aktivitasnya sehingga mencapai fase stabil. Selain itu sisa lumpur kecap yang tidak termanfaatkan dapat menyebabkan peningkatan $\mathrm{pH}$, karena lumpur kecap memiliki derajat keasaman yang relatif netral. Peningkatan $\mathrm{pH}$ tersebut memberikan peluang untuk tumbuhnya penambahan lumpur kecap memberikan pengaruh berbeda nyata $(\mathrm{P}<0,05)$ terhadap $\mathrm{pH}$ silase pelepah pisang. Perlakuan P1 berbeda nyata $(\mathrm{P}<0,05)$ dengan $\mathrm{P} 2, \mathrm{P} 3$, dan P4. Namun tidak ada perbedaan nyata ( $>>0,05)$ pada perlakuan P2,P3, dan P4. Perbedaan $\mathrm{pH}$ ini dapat disebabkan konsentrasi aditif lumpur kecap pada silase yang berbeda-beda. Perbedaan konsentrasi aditif mempengaruhi kandungan karhohidrat terlarut yang ada dalam fermentasi anaerob. Karbohidrat tersebut dimanfaatkan oleh mikroba anaerob terutama bakteri asam laktat sebagai asupan energinya. Semikin tinggi penggunaan aditif lumpur kecap dapat merangsang tumbuh kembangnya bakteri asam laktat. Peningkatan bakteri asam laktat akan berbanding lurus dengan meningkatnya kandungan asam laktat. Tingginya kandungan asam laktat diduga dapat menurunkan nilai $\mathrm{pH}$. Menurut Adriani (2008, 2014); Sanjaya (2010); Mushawwir dkk., (2010, 2011, 2015, 2020) dan Susilawati et al. (2019), Karbohidrat yang tinggi sangat menentukan produksi asam terutama asam laktat dan asam organik lainnya di dalam proses ensilase sehingga dapat mempercepat penurunan derajat keasaman.

Penurunan $\mathrm{pH}$ yang cepat dapat membatasi pemecahan protein dan 
menghambat pertumbuhan mikroorganisme anaerobik merugikan seperti entrobacteria dan clostridia (Santi dkk., 2012; Tanuwiria
$\mathrm{pH}$ 5,15 termasuk ke dalam kategori jelek, (P2) dengan penambahan lumpur kecap sebanyak 3\% menghasilkan cairan ekstrak

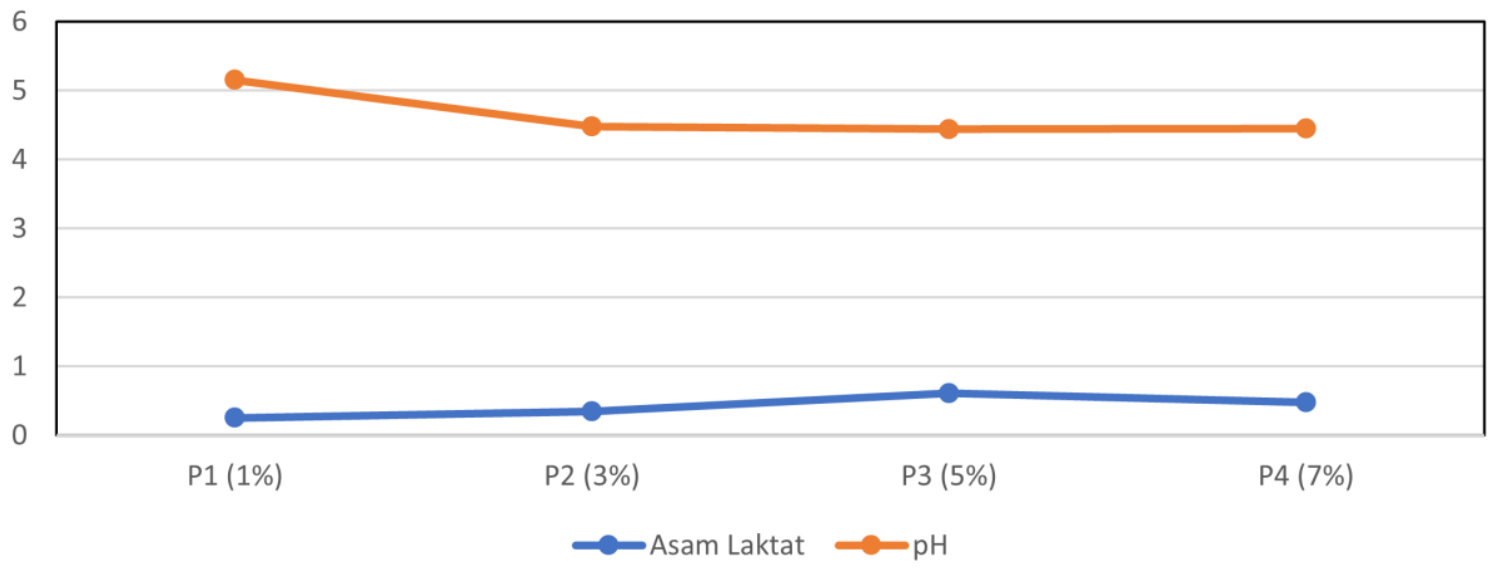

Gambar 1. Histogram Pengaruh Penggunaan Aditif Lumpur Kecap Terhadap Kandungan Asam Laktat dan pH Silase Pelepah Pisang.

dkk., 2020). Peningkatan $\mathrm{pH}$ dapat dikarenakan mikroba tidak dapat lagi memanfaatkan zat makanan dalam lumpur kecap, karena asam laktat yang dihasilkan telah menghentikan aktivitasnya sehingga $\mathrm{pH}$ tidak dapat diturunkan lagi bahkan cenderung naik. McDonald et. al (1991), menyatakan bahwa tingkat keasaman yang semakin tinggi secara perlahan akan terakumulasi dan membunuh bakteri asam laktat itu sendiri. Pada fase tersebut dapat menstabilkan $\mathrm{pH}$ dikarenakan tidak terjadi lagi produksi asam oleh bakteri asam laktat. Selain itu sisa lumpur kecap yang tidak termanfaatkan dapat menyebabkan peningkatan $\mathrm{pH}$, karena lumpur kecap memiliki derajat keasaman yang relatif netral atau lebih tinggi dari $\mathrm{pH}$ yang diharapkan yaitu kisaran 3,5-4,2.

Beberapa penelitian antara lain Tanuwiria (2004, 2007a,b); Tanuwiria dkk. (2007); Adawiah dkk., (2007); Siregar (1996) mengkategorikan kualitas silase berdasarkan pH-nya yaitu : 3,5-4,2 baik sekali, 4,2-4,5 baik, 4,5-4,8 sedang dan lebih dari 4,8 adalah jelek. Dengan demikian $\mathrm{pH}$ yang dihasilkan dari penelitian ini pada setiap perlakuannya berbeda-beda. Penambahan lumpur kecap sebanyak $1 \% \quad(\mathrm{P} 1)$ menghasilkan cairan ekstrak dengan rataan dengan rataan $\mathrm{pH} 4,48$ termasuk ke dalam kategori baik, (P3) dengan penambahan lumpur kecap sebanyak 5\% menghasilkan cairan ekstrak dengan rataan $\mathrm{pH} 4,48$ termasuk ke dalam kategori baik, dan (P4) dengan penambahan lumpur kecap sebanyak 7\% menghasilkan cairan ekstrak dengan rataan $\mathrm{pH} 4,53$ termasuk ke dalam kategori sedang. Hasil tersebut diperkuat dengan hasil penelitian Lukmansyah dkk. (2009) yang menyatakan bahwa lumpur kecap yang optimal digunakan sebagai bahan tambahan pada pembuatan silase adalah 5\% dari berat hijauan, dan Wolford (1984) menyatakan bahwa penggunaan aditif sebanyak 4-5\% dapat menghasilkan silase yang baik.

\section{KESIMPULAN}

Penggunaan aditif lumpur kecap sebanyak 5\% dapat menghasilkan kandungan asam laktat silase pelepah pisang tertinggi dan penggunaan aditif lumpur kecap sebanyak 3\% menghasilkan kandungan $\mathrm{pH}$ silase pelepah pisang terendah.

\section{DAFTAR PUSTAKA}

Adawiah, A., T. Sutardi, T. Toharmat, W. Manalu, N. Ramli, dan U.H. 
Tanuwiria. 2007. Respons terhadap suplementasi sabun mineral dan mineral organik serta kacang kedelai sangrai pada indikator fermentabilitas ransum dalam rumen domba. Media Peternakan 30:162-169.

Adriani, L. dan A. Mushawwir. 2008. Kadar Glukosa Darah, Laktosa Dan Produksi Susu Sapi Perah Pada Berbagai Tingkat Suplementasi Mineral Makro. Fakultas Peternakan Universitas Padjadjaran.

Adriani, L., A. Rochana. A.A. Yulianti, A. Mushawwir, and N. Indrayani. 2014. Profil serum glutamate oxaloacetat transaminase (SGOT) and glutamate pyruvate transaminase (SGPT) level of broiler that was given noni juice (Morinda citrifolia) and palm sugar (Arenga piata). Lucrări Ştiinţifice Seria Zootehnie. 62:101-105.

Badan Pusat Statistik dan Direktorat Jenderal Hortikultura. 2019. Luas Panen Pisang Menurut Provinsi, Tahun 2015-2019.

Bolsen, K.K. 1993. Prinsip Dasar Silase. Diterjemahkan oleh R.B. Sudjono. Kansas State University, Manhattan, Kansas.

Cappucino, J.G. and N. Sherman. 1991. Microbiology : A Laboratory Manual. Rockland Community College, State University of New York.

Chen, Y. and Z. G. Weinberg. 2008. Changes during aerobic exposure of wheat silage. Anim. Feed Sci. Technology. 154:76-82.

Ffoulkes, D. S. Espejo, D. Marie, M. Delpeche and T. R. Preston. 1977. The banana plant as cattle feed: Composition and biomass production. Trop. Anim. Prod. 3:45-50

Hernawan, E., L. Adriani, and U.H. Tanuwiria. 2015. Dry matter digestibility, VFA and $\mathrm{NH}_{3}$ production in vitro of sheep rations supplemented sweet orange waste. Scientific PapersAnimal Science Series: Lucrări Ştiinţifice - Seria Zootehnie. 63:81-86.

Laboratorium Nutrisi Ternak Ruminansia dan Kimia Makanan Ternak. 2008.
Kandungan Nutrien Lumpur Kecap. Fakultas Peternakan Universitas Padjadjaran, Sumedang.

Laboratorium Nutrisi Ternak Ruminansia dan Kimia Makanan Ternak. 2011. Kandungan Nutrien Batang Pisang. Fakultas Peternakan Universitas Padjadjaran, Sumedang.

Lukmansyah, D., T. Dhalika, Mansyur, A. Budimana, dan I. Hernaman. 2009. Substitusi molasses dengan hasil ikutan industry kecap terhadap kualitas silase rumput gajah cv Taiwan. Buletin Ilmu Peternakan dan Perikanan. 13:21-28.

McDonald, P., N. Henderson, and S. Heron. 1991. The Biochemistry of silage. $2^{\text {nd }}$ ed., Chalombe Publication.

Mushawwir, A. Y.K. Yong, L. Adriani, E. Hernawan, K.A. Kamil. 2010. The fluctuation effect of atmospheric ammonia $\left(\mathrm{NH}_{3}\right)$ exposure and microclimate on hereford bulls hematochemical. J. of the Indon Tropical Anim Agric. 35:232-238.

Mushawwir, A., L.Adriani, and K.A. Kamil. 2011. Prediction models for olfactory metabolic and sows\% RNAreticulocyt (RNArt) by measurement of atmospheric ammonia exposure and microclimate level. J. of the Indon Tropical Anim Agric. 36:14-20.

Mushawwir, A. 2015. Biokimi Nutrisi. Widya Padjadjaran, Bandung.

Mushawwir, A., A.A. Yulianti, N. Suwarno, dan R. Permana. 2020. Profil metabolit plasma darah dan aktivitas kreatin kinase sapi perah berdasarkan fluktuasi mikroklimat lingkungan kandangnya. J. Veteriner. 21:24-30.

Mutaqin, B.K., D. S. Tasripin, L. Adriani, and U. H.Tanuwiria. 2019. Effect of the addition of Ca-PUFA complexes to complete rations on fermentability and digestibility. Pakistan J. of Nutrition. 18:519-523.

Pangestu, E., T. Toharmat, dan U.H. Tanuwiria. 2003. Nilai nutrisi ransum berbasis limbah industri pertanian pada sapi perah laktasi. J. Indon. Trop. Anim. Agric. 28:166-171. 
Pangestu, E., T. Toharmat, dan U.H. Tanuwiria. 2003. Nilai nutrisi ransum berbasis limbah industri pertanian pada sapi perah laktasi. J. Indon. Trop. Anim. Agric. 28:166-171.

Santi, R., D. Fatmasari, S.D. Widyawati, dan W.P.S. Suprayogi. 2012. Kualitas dan nilai kecernaan in vitro silase batang pisang (Musa Paradisiaca) dengan penambahan beberapa akselarator. Tropical Animal Husbandry. 1:15-23.

Santosa, U., U.H. Tanuwiria, A. Yulianti, dan U. Suryadi. 2012. Pemanfaatan kromium organik limbah penyamakan kulit untuk mengurangi stres transportasi. J. Ilmu Ternak dan Veteriner. 17:132-141.

Siregar, M.E. 1996. Pengawetan Pakan Ternak. Penebar Swadaya. Jakarta.

Susilawati, I., N.P. Indriani, L. Khairani, and U.H. Tanuwiria. 2019. Increase nutritional content and in vitro digestibility of forage legumes by adding molybdenum with foliar spray methods. Legume Research: An International J. 42: 36-41

Sutowo, I. T., Adelina, dan D. Febrina. 2016. Kualitas nutrisi silase limbah pisang (batang dan bonggol) dan level molases yang berbeda sebagai pakan alternatif ternak ruminansia. J. Peternakan. 13:41-47.

Suwarno, N., dan A. Mushawwir. 2019. Model prediksi metabolit melalui jalur glikogenolisis berdasarkan fluktuasi mikroklimat lingkungan kandang sapi perah. J. Ilmu dan Industri Peternakan. 5:77-86.

Tanuwiria, U.H. 2004. Efek suplementasi $\mathrm{Zn}-\mathrm{Cu}$ proteinat dalam ransum terhadap fermentabilitas dan kecernaan in vitro. J. Ilmu Ternak. 4:7-12.

Tanuwiria, U.H. 2007a. Proteksi protein tepung ikan oleh berbagai sumber tannin dan pengaruhnya terhadap fermentabilitas dan kecernaannya (in vitro). J. Agroland. 14:56-60.

Tanuwiria, U.H., 2007b. Efek suplementasi kompleks mineral-minyak dan mineral-organik dalam ransum terhadap kecernaan ransum, populasi mikroba rumen dan performa produksi domba jantan. Prosiding Seminar Nasional dan Kongres Asosiasi Ahli Nutrisi. AINI. 1:23-27.

Tanuwiria, U.H., A. Mushawwir, dan A.A. Yulianti. 2007. Potensi pakan serat dan daya dukungnya terhadap populasi ternak ruminansia di wilayah kabupaten Garut. Jurnal Ilmu Ternak. 7:11-16.

Tanuwiria, U.H., D. Tasrifin, dan A. Mushawwir. 2020. Respon gamma glutamil transpeptidase $(\gamma-\mathrm{gt})$ dan kadar glukosa sapi perah pada ketinggian tempat (altitude) yang berbeda. J. Ilmu dan Industri Peternakan. 6:25-34.

Woolford, M.K. 1984. The Silage Fermentation. Marcel dekker Inc. New York. 